\title{
Production and optimization of a-amylase from thermo-halophilic bacteria isolated from different local marine environments
}

\author{
Eman A. Elmansy ${ }^{1 *}$, Mohsen S. Asker ${ }^{1}$, Ebtsam M. El-Kady ${ }^{1}$, Saadia M. Hassanein ${ }^{2}$ and Fawkia M. El-Beih²
}

\begin{abstract}
Background: Amylases are among the most important enzymes which are of great significance for biotechnology and have almost completely replaced chemical hydrolysis of starch in the starch processing industry. The present study was concerned with the production and optimization of extracellular a-amylase from Bacillus sp. NRC22017.

Results: The effect of various fermentation conditions on a-amylase production through shake-flask culture was investigated. Bacterial strain produces a-amylase was isolated from water in Wadi El-Natron. Based on microbiological, biochemical tests, and 16S rRNA gene sequences, the isolate was identified as Bacillus sp. NRC22017 and was later used for further studies. Maximum yield of a-amylase is $15.15 \pm 0.47 \mathrm{U} / \mathrm{ml}$ from Bacillus sp. NRC22017; this strain is characterized with high temperature and high salinity in cultivated culture, and achieved maximum yield of a-amylase at pH 6.0 with inoculum size of $500 \mu \mathrm{l}$ at $45^{\circ} \mathrm{C}$ and aerobically incubation period of $72 \mathrm{~h}$. The optimum volume of the fermentation medium was found to be $20 \mathrm{ml}$ in $100 \mathrm{ml}$ Erlenmeyer flask; the best starch and meat extract plus peptone concentration that provided the highest enzyme production from Bacillus sp. NRC22017 were found to be $2 \%$ and $1.05 \%$ $(w / v)$ respectively.
\end{abstract}

Conclusion: Enzyme production was higher after optimizing the production conditions as compared to the basal medium.

Keywords: a-Amylase, Starch hydrolysis, Thermo-halophilic bacteria

\section{Background}

Alpha amylase (EC: 3.2.1.1), randomly attack $\alpha-1$, 4-glycosidic bond of starch, maltodextrins, maltose, and glucose units were formed as a result of $\alpha$-amylase action (Maity et al. 2015). Alpha amylase has gained a great attention due to its broad spectrum of applications and economic merits (Bansode 2010). Currently, amylase production has reached up to $65 \%$ of enzyme market in the world and is continuously increasing (Abdullah et al. 2014). It has a wide range of applications in starch liquefaction, paper, desizing of textile fabrics, preparing starch coatings of paints, removing wallpaper, brewing industry, sugar induction by the production of sugar syrups, and pharmaceuticals. Alpha amylase can be produced by micro- and macroorganisms (Simair et al. 2017). When the

\footnotetext{
* Correspondence: emmyahmed36@yahoo.com

${ }^{1}$ Microbial Biotechnology Department, National Research Centre, El-Tahreer

Street, Dokki, Cairo, Egypt

Full list of author information is available at the end of the article
}

origins are in comparison, amylases from animal and plant origins have low resistance under acidic, basic, and high temperature conditions. On the other hand, bacterial and fungal amylases have good stability under such conditions and have more economic production operations. So, microbial enzymes have been applied in a large number of applications.

Recently, starch saccharification, the main use of amylase, has totally displaced chemical utilization with amylase enzyme hydrolysis. Saccharification is executed at raised temperature and thermophilic microorganisms could be most hopeful candidates for amylase production because these strains will produce thermostable amylase. This is why, still, search for new microbial strains is continued to achieve industrial requirements of enzymes.

In addition, amylase is supplemented in local detergents due to high alkaline $\mathrm{pH}$ stability needed for industries (Asad et al. 2011). Moreover, thermophilic amylase 
is required for other applications in the production of sweeteners from starch and saccharification of starch for biochemical production (Castro et al. 1999).

Bacillus genus is famous for alpha-amylase production and several Bacillus strains such as B. stearothermophilus, B. subtilis, B. cereus, B. licheniformis, and B. amyloliquefaciens are isolated and screened for amylase production (Sivaramakrishnan et al. 2006). Some Bacillus strains are involved in raw starch degradations (Demirkan et al. 2005; Goyal et al. 2005; Puspasari et al. 2013).

Still, many are being searched to obtain the maximum output with unique industrial properties. Enzyme production could be improved through the optimization of various physical and nutritional growth parameters; the important factors that determine the bioprocess are incubation period, temperature, $\mathrm{pH}$, aeration, inoculum size, carbon, and nitrogen sources. Therefore, in this study, the effects of physical and nutritional parameters were investigated for the optimum production of extracellular enzyme $\alpha$-amylase from Bacillus sp. NRC22017.

\section{Results}

\section{Isolation, screening, and identification of amylolytic} bacteria

In the present investigation, a pure strain of Bacillus sp. NRC22017 was isolated from Wadi El-Natron and we found bacteria isolated from such places may have better potential to produce enzyme under adverse conditions. The isolate was inspected for the qualitative production of $\alpha$-amylase on a starch agar plate supplemented with $2 \%$ soluble starch using iodine solution (Fig. 1). Finally, NRC22017 strain was selected as the best amylase producer. The promising isolate (NRC22017) was identified based on its microscopic, morphological, and biochemical characterization and it was proven to be Bacillus sp. (Table 1).
Table 1 Cultural and biochemical characteristic of the promising bacterial isolate

\begin{tabular}{ll}
\hline Test & Bacillus sp. NRC22017 \\
\hline Morphological characterization & \\
Gram stain & Positive \\
Motility & Positive \\
Spore-former & Positive \\
Appearance of the colony surface & Wrinkled \\
Color & Creamy \\
Elevation & Umbonate \\
Edge & Entire \\
Whole colony & Circular \\
Pigmentation & No pigment \\
Opacity of the bacterial colony & Opaque \\
Biochemical characterization & \\
Starch hydrolysis & Positive \\
Voges-Proskauer & Negative \\
Citrate utilization & Negative \\
Nitrate reduction & Negative \\
Oxidase & Positive \\
Catalase & Positive \\
Acid production from & Positive \\
Glucose & Positive \\
Fructose & Negative \\
Galactose & Negative \\
Lactose & Negative \\
Maltose & Positive \\
Sucrose & Positive \\
Mannose & \\
\hline
\end{tabular}

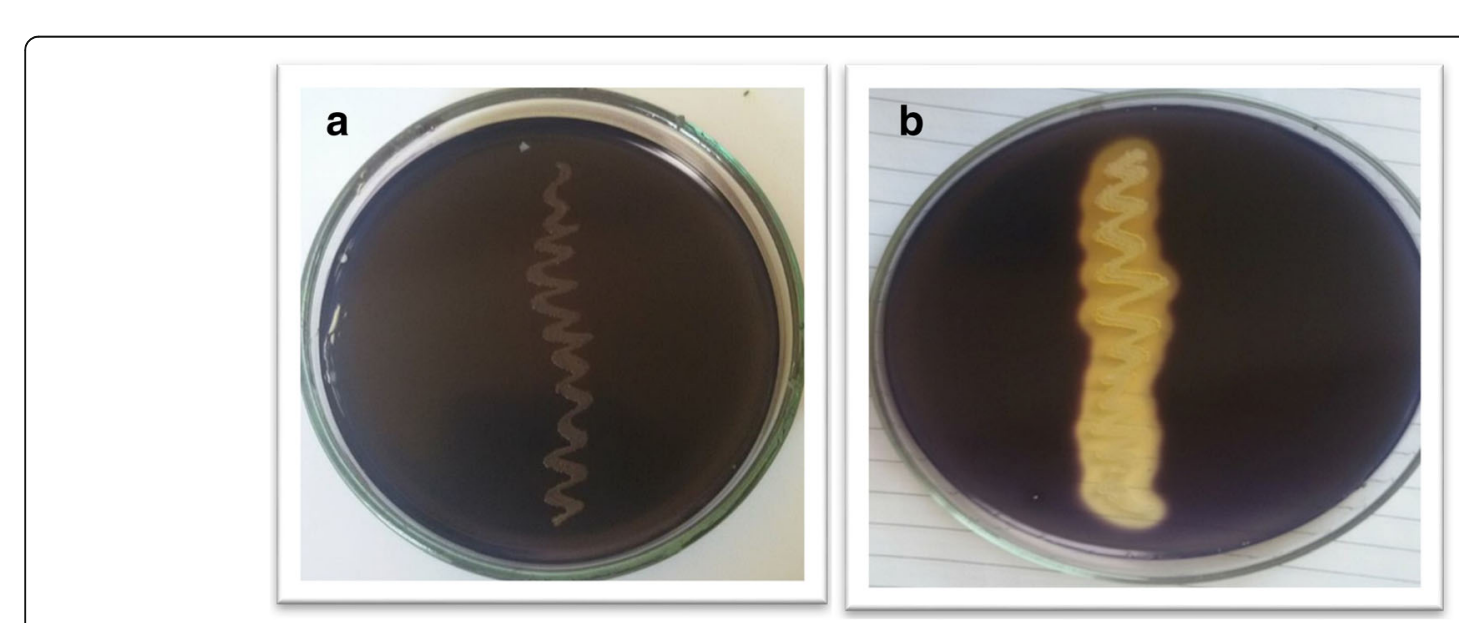

Fig. 1 Bacterial isolate negative for starch hydrolysis test (a). Zone of clearance around NRC22017 (b) due to starch hydrolysis 
A molecular technique was used to prove and further confirm the identification of the isolate to the species level. The partial $16 \mathrm{~S}$ rDNA sequence was determined and was compared to the GenBank databases. The isolate was identified as Bacillus sp. NRC22017. The sequence was submitted to GenBank in NCBI (https:// www.ncbi.nlm.nih.gov/nuccore/KY614074) with the accession number KY614074. The phylogenetic tree based on different species of Bacillus was constructed using neighbor joining method (Fig. 2).

\section{Optimization of a-amylase production conditions}

Though different Bacillus species have similar growth patterns and enzyme profiles, but their optimized conditions vary, depending upon the strain. Optimization of the process parameters is needed for the improved production of the enzyme to make the process cost effective. Selected strain Bacillus sp. NRC22017 was subjected to various culture conditions to investigate the optimum culture conditions for $\alpha$-amylase production.

\section{Effect of five different fermentation media on alpha amylase production}

Studies on bacterial growth and $\alpha$-amylase production from Bacillus sp. NRC22017 in shake-flask cultures were carried out using five different media at $\mathrm{pH} 7.0$ and incubated for $72 \mathrm{~h}$ at $50{ }^{\circ} \mathrm{C}$. Results in Fig. 3 illustrated that among the culture media, the medium 5 exhibited a significant impact on the microorganism development $(2.15 \pm 0.067)$ and enzyme production $(11.02 \pm 0.17 \mathrm{U} / \mathrm{ml})$, while the lowest growth rate $(0.089 \pm 0.001)$ and $\alpha$-amylase synthesis $(3.20 \pm$ $0.12 \mathrm{U} / \mathrm{ml}$ ) were obtained when medium 3 was used.

Effect of physical parameters on alpha amylase production Incubation period The results obtained from the incubation time study in submerged culture cleared that bacterial growth and $\alpha$-amylase productivity was gradually

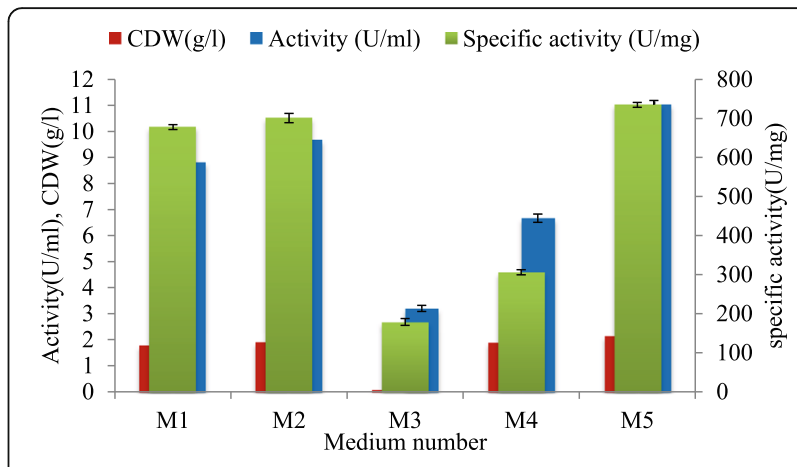

Fig. 3 Production of a-amylase by Bacillus sp. NRC22017 in five different fermentation media. Data were expressed as mean \pm standard error

raised with the increment in the incubation period. Incubation for 3 days was the best for both $\alpha$-amylase productivity $(11.56 \pm 0.20 \mathrm{U} / \mathrm{ml})$ and bacterial growth $(2.04 \pm$ $0.09 \mathrm{~g} / \mathrm{l})$. The activity of $\alpha$-amylase was declined by further increasing the incubation period. At 5 days of incubation, it was extremely reduced and the minimum amount of $\alpha$-amylase was obtained after 5 days of incubation $(6.96 \pm 0.17 \mathrm{U} / \mathrm{ml})$ (Fig. 4a).

Inoculum size Data in Fig. 4b show the effect of inoculum size (200 to $700 \mu \mathrm{l} v / v)$ on cell growth and extracellular amylase secretion. The highest amylase yield was achieved when $500 \mu \mathrm{l}(14.24 \pm 0.2 \mathrm{U} / \mathrm{ml})$ of 24 -h-old seeds culture was inoculated into the fermentation medium.

Incubation temperature Data in Fig. 4c show the effect of fermentation temperature $\left(40-55^{\circ} \mathrm{C}\right)$ on the synthesis of amylase by Bacillus sp. NRC22017 grown in fermentation medium containing $20 \mathrm{~g} / \mathrm{l}$ starch and $14 \mathrm{~g} / \mathrm{l}$ peptone plus yeast extract at $\mathrm{pH} 7.0$ and incubated for $72 \mathrm{~h}$. Enzyme concentration increased with incubation temperature and maximum amylase yield was noted at

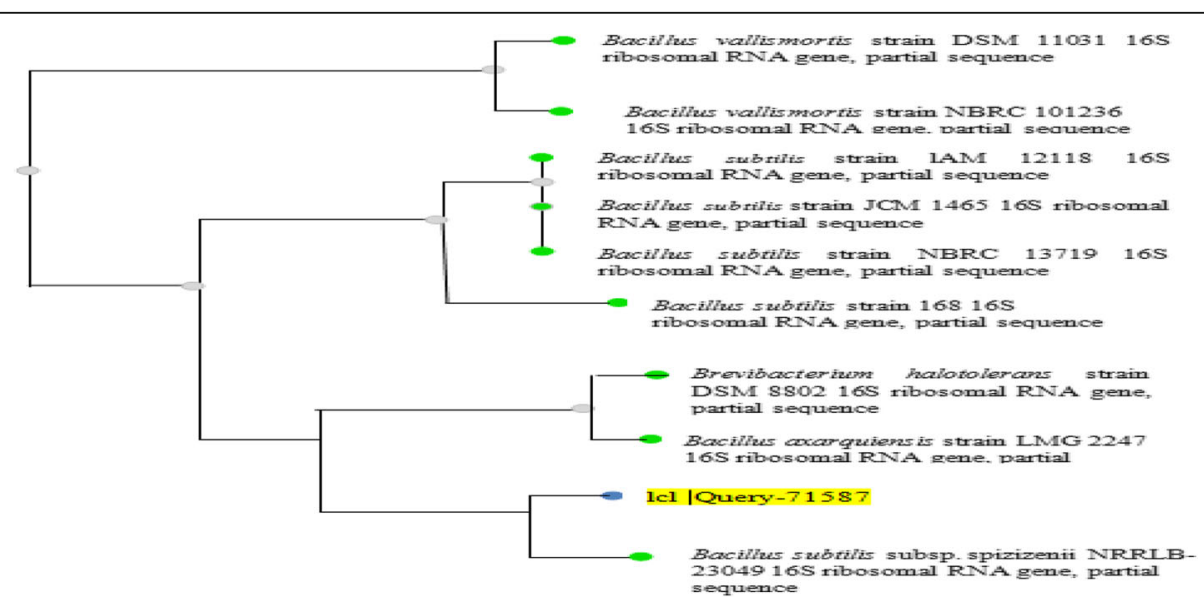

Fig. 2 Phylogenetic tree based on the 16S rRNA sequences of isolate and its closest Bacillus sp. 

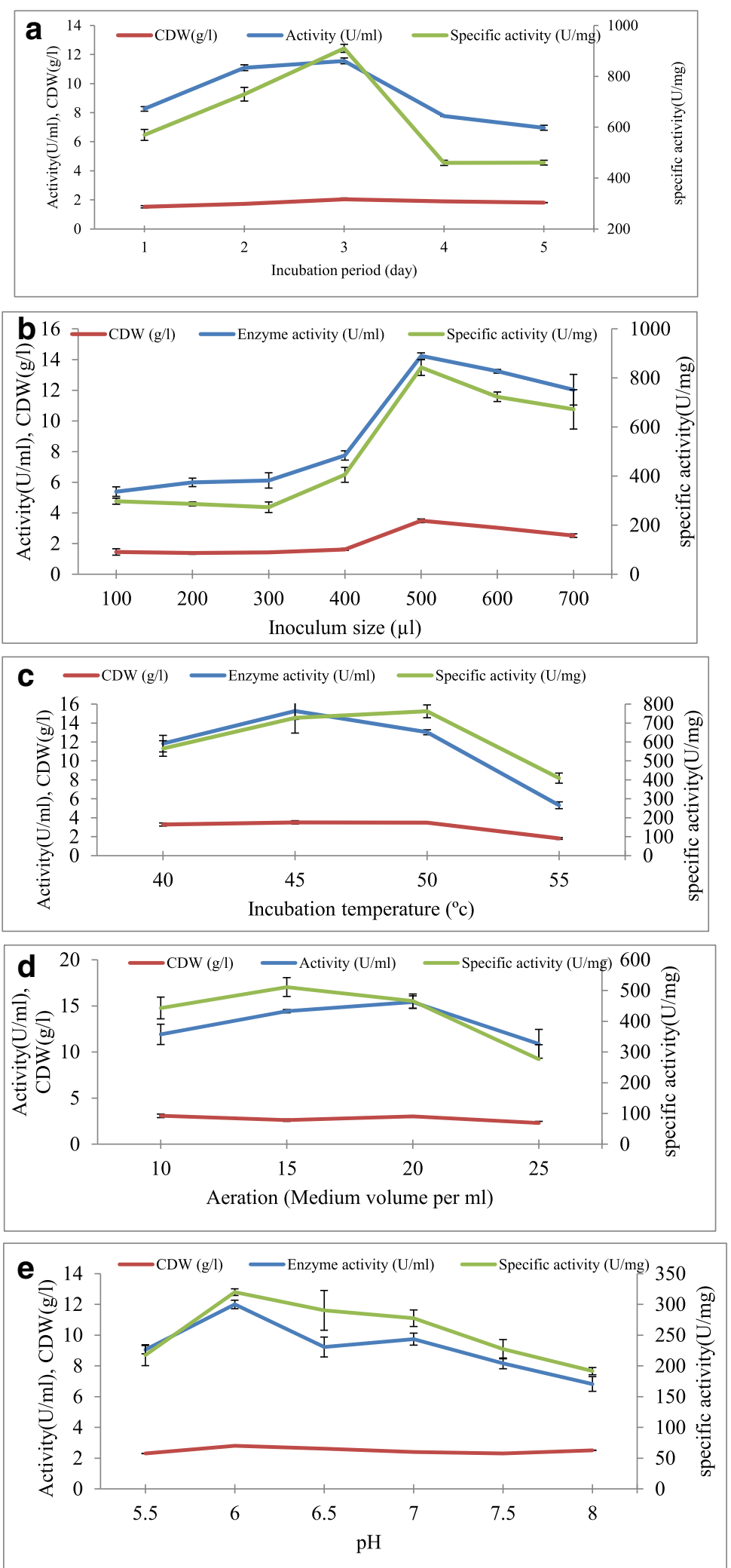

Fig. 4 Effect of incubation period (a), inoculum size (b), incubation temperature (c), medium volume in $100 \mathrm{ml}$ conical flask (d), and different pH values (e) on a-amylase production by Bacillus sp. NRC22017. Data were expressed as mean \pm standard error 
$45{ }^{\circ} \mathrm{C}(15.27 \pm 0.88 \mathrm{U} / \mathrm{ml})$ and a further increase of temperature reduced amylase synthesis. The production of the enzyme was greatly inhibited at $55^{\circ} \mathrm{C}(5.32 \pm 0.36)$.

Aeration In our study, the highest productivity of $\alpha$-amylase was recorded at $20 \mathrm{ml}$ broth medium in $100 \mathrm{ml}$ conical flask $(15.42 \pm 0.68 \mathrm{U} / \mathrm{ml})$, and the lowest production level was reported at $25 \mathrm{ml}$ broth medium in a conical flask of $100 \mathrm{ml}$ capacity $(10.89 \pm 1.57 \mathrm{U} / \mathrm{ml})$ (Fig. 4d).

pH In our study, the maximum bacterial growth and synthesis of $\alpha$-amylase were found at pH 6.0 (12.00 \pm $0.28 \mathrm{U} / \mathrm{ml}$ ) (Fig. 4e).

\section{Effect of nutritional factors on a-amylase production}

Various carbon sources Different carbon sources (starch, sucrose, fructose, xylose, and maltose) at a concentration of $2.0 \%(w / v)$ were individually tested in the basal medium at optimal temperature, incubation period, and $\mathrm{pH}$ to observe the effect on enzyme synthesis by $\mathrm{Ba}$ cillus sp. NRC22017. Out of these carbon sources, maltose was found to be the best for amylase production (13.74 \pm $0.02 \mathrm{U} / \mathrm{ml}$ ) within $72 \mathrm{~h}$ (Fig. 5a). Even though the maximum activity of $\alpha$-amylase enzyme was observed in the existence of maltose as a carbon source, starch is used for supplementation in the production process, because it works as an inexpensive source as compared with maltose. From the present findings, it was evident that the enhancement of $\alpha$-amylase needs substrates with $\alpha-1,4$ glycosidic bonds, including starch and maltose.

The influence of starch concentration as a carbon source on $\alpha$-amylase production from Bacillus sp. NRC22017 was clarified in Fig. 5b. The amount of $\alpha$-amylase increase until it reaches the highest level at a starch concentration of $2 \%(w / v)(12.42 \pm 0.06 \mathrm{U} / \mathrm{ml})$, then it starts to decrease.

Various nitrogen sources The various organic nitrogen sources impact on bacterial growth and $\alpha$-amylase production from Bacillus sp. NRC22017 was shown in Fig. 5c. Supplementation of yeast extract plus meat extract to the fermentation medium gave the highest bacterial growth and enzyme productivity $(14.17 \pm 0.20 \mathrm{U} / \mathrm{ml})$.

Figure 5d demonstrated that Bacillus sp. NRC22017 gave the highest $\alpha$-amylase productivity at $1.05 \%$ meat plus yeast extract $(15.15 \pm 0.47 \mathrm{U} / \mathrm{ml})$. Also, from the obtained data, it was obvious that bacterial growth increase with increasing nitrogen source concentration and the highest cell dry weight was obtained at the highest nitrogen source concentration $(1.4 \%)(4.67 \pm 0.18 \mathrm{~g} / \mathrm{l})$, but $\alpha$-amylase synthesis decreased with increasing nitrogen source concentration above the optimum concentration.

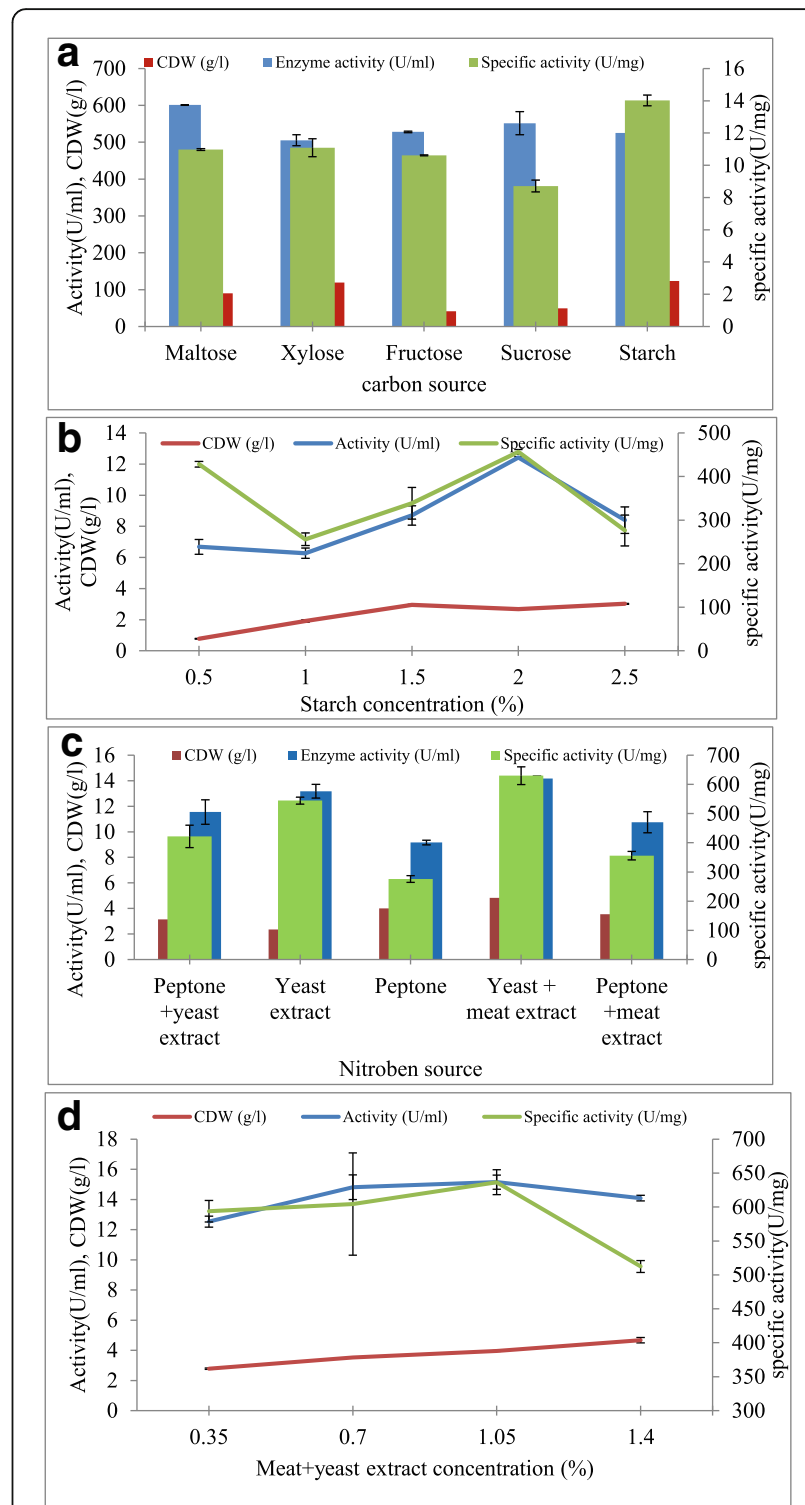

Fig. 5 Effect of different carbon sources (a), different concentrations of starch (b), different nitrogen sources (c), and different concentrations of yeast extract plus meat extract (d) on a-amylase production by Bacillus sp. NRC22017. Data were expressed as mean \pm standard error

\section{Discussion}

The initial screening of Bacillus sp. NRC22017 strain revealed zones of hydrolysis on starch agar plates. This clear zone indicated that NRC22017 $\alpha$-amylase can hydrolyze starch.

In the present study, we observed $72 \mathrm{~h}$ as the optimum growth period for the presently reported Bacillus strain and longer incubation period supported less number of colonies and lower enzyme activity. A prolonged incubation period extremely reduced $\alpha$-amylase possibly due to the exhaustion of nutrients, death of microorganisms, gathering of byproducts in the medium 
such as toxins, inhibitors, proteolysis of $\alpha$-amylase by proteases enzymes, and also the cells may attained the decline phase and showed diminished amylase synthesis (Teodoro and Martins 2000; Aiyer 2005). These findings were closely similar to the results of $B$. licheniformis ATCC 12759 (Nurullah 2011) and Bacillus isolates (Kanimozhi et al. 2014). While, Kaur and Vyas (2012), Deb et al. (2013), Singh et al. (2016), and Paul et al. (2017) found that an extended period of incubation beyond $48 \mathrm{~h}$ did not increase the enzyme production from Bacillus sp. DLB, B. amyloliquefaciens P-001, Bacillus sp. strain B-10, and Bacillus sp. MB6, respectively. These results were in contradiction with our results in the present study.

Concerning inoculum size, this study proposed that $\alpha$-amylase output from Bacillus sp. strain depends on the growth. Our results are almost in harmony with literature for enzyme production from different strains concerning inoculum size. The size of inoculum plays a notable role in the fermentation rate. It is noteworthy that there is no precise bacterial inoculum volume suitable for amylase production. It can vary from $0.5 \%$ for $B$. amyloliquefaciens (Haq et al. 2010) to 2.95\% (Zambare 2011) for Bacillus sp. and $8 \%$ for B. cereus (Sivakumar et al. 2012).

Temperature is a highly sensitive parameter for $\alpha$-amylase productivity and so it needs to be controlled and this is usually varied from organism to another (Sivakumar et al. 2011). Temperature can affect an enzyme in two ways. One is a direct influence on the reaction rate constant, and the other is in thermal denaturation of the enzyme at elevated temperatures (Demirkan et al. 2017). Similarly, Vijayaraghavan et al. (2015) and Asad et al. (2011) obtained maximum amylase secretion from Bacillus cereus IND4 and Bacillus sp. WA21 at $45{ }^{\circ} \mathrm{C}$ on starch agar medium, whereas Hasan et al. (2017) reported maximum amylase production was at moderate temperature $\left(37^{\circ} \mathrm{C}\right)$ for both Chryseobacterium and Bacillus isolates.

During fermentation, the aeration rate indirectly indicates the dissolved oxygen level in the fermentation broth. Yegneswaran and Gray (1991) reported that a high concentration of oxygen had an influencing effect on microbial growth and enzyme production. The biosynthesis of $\alpha$-amylase was diminished with the increase in the broth volume; this behavior might probably because of a reduction in air supply as a result of the drooping in the agitation rate of medium that happened with a high volume of fermentation medium (Narang and Satyanarayana 2001). Riaz et al. (2003) and Dash et al. (2015) conveyed that the maximum yield of $\alpha$-amylase from B. subtilis GCBUCM- 25 and B. subtilis BI19 was gained at 25 and $50 \mathrm{ml}$ of enzyme production medium in $250 \mathrm{ml}$ Erlenmeyer flask respectively.
Different enzymes have different optimum $\mathrm{pH}$ values. This is the $\mathrm{pH}$ value at which the bonds within them are affected by $\mathrm{H}^{+}$and $\mathrm{OH}^{-}$ions in a way that the shape of the active site is the most complementary to the shape of the substrate. At the ideal $\mathrm{pH}$, the rate of reaction is optimum. Any alteration in $\mathrm{pH}$ above or below the optimum will quickly cause a decline in the reaction rate, since more of the enzyme molecules will have active sites whose shapes are not (or at least are less) complementary to the shape of their substrate (Demirkan et al. 2017). Similar result has been recorded for Bacillus sp. and Brevibacillus borstelensis R1 (Singh et al. 2012, Suribabu et al. 2014). The production optimization studies showed that maximum enzyme production by Penicillium notatum IBGE 03 was obtained at $\mathrm{pH} 5.5$ (Ahmed et al. 2015). In neutral conditions ( $\mathrm{pH}$ 6.5-7.5), the $\alpha$-amylase production was reported in Bacillus sp. (Asgher et al. 2007), and Bacillus sp. NRC12017 (Elkady et al. 2017). In alkaline conditions ( $\mathrm{pH} 7.5-11.0)$, the $\alpha$-amylase production was reported in Bacillus sp. (Saxena et al. 2007). It was stated that at high $\mathrm{pH}$, the metabolic action of bacterium may be suppressed and thus it inhibits the enzyme production (Ellaiah et al. 2002).

Regarding the effect of different carbon sources on alpha amylase production by Bacillus sp. NRC22017, results obtained were in agreement with results of NandLal et al. (2017) in Bacillus licheniformis JAR-26; Thippeswamy et al. (2006) in Bacillus species $\left(B_{3}\right)$ where highest amylase production $(0.464 \mathrm{U} / \mathrm{ml})$ was induced by maltose. Suribabu et al. (2014) also found maltose better than other carbon sources examined for $\alpha$-amylase production with Brevibacillus borostelensis R1 under submerged fermentation. Whereas Elkady et al. (2017) and Gangadharan et al. (2006) reported that Bacillus sp. NRC12017 and Bacillus amyloliquefaciens gave the highest enzyme yield with soluble starch, followed by maltose. Bacillus sp. NRC22017 could grow and produce $\alpha$-amylase in the presence or absence of starch from the fermentation medium. Sucrose, fructose, and starch have almost similar effect on $\alpha$-amylase synthesis from Bacillus sp. NRC22017 (12.61 \pm $0.72,12.07 \pm 0.05$, and $12.01 \pm 0.17 \mathrm{U} / \mathrm{ml}$ ), respectively.

There was a decrease in enzyme production at excessive starch concentration and this might be imputed to the rapid consumption of starch leading to the release of toxic metabolic wastes which suppress the growth of bacteria and $\alpha$-amylase production. Also, high starch concentrations caused the broth culture to be more viscous, thus interfering with $\mathrm{O}_{2}$ transfer resulting in restriction of dissolved $\mathrm{O}_{2}$ required for the microbial growth. Similarly, Mishra and Behera (2008) found that raising the starch concentration increased both growth and $\alpha$-amylase production by Bacillus strain from kitchen wastes and the maximum yield of the enzyme was reached at a starch concentration of $2 \%$. While 
Tiwari et al. (2014) informed that $4 \%$ soluble starch concentration was the best for amylase production by B. tequilensis RG-01 and above this concentration enzyme production was slightly decreased tested.

Nitrogen source is another essential nutrient that is required by the microorganisms in comparatively larger amounts. Nitrogen source type and relative concentration in the growth medium are important for both microbial growth and amylase production (NandLal et al. 2016). The nitrogen is metabolized to produce primarily amino acids, nucleic acids, protein, enzymes, and other cellular components that play a vital role in metabolism. The decrease in $\alpha$-amylase production at excess nitrogen levels could be due to the $\mathrm{pH}$ depression or the stimulation of protease enzyme, which repress the amylolytic activity (Tonkova 2006). Both lower and higher nitrogen sources levels in the production broth are equally detrimental and cause inhibition of the enzyme (Sharma et al. 2012).

\section{Conclusion}

In this study, a combination of physical and chemical parameters was employed to maximize $\alpha$-amylase synthesis. By optimizing the incubation conditions of $\alpha$-amylase production from Bacillus sp. NRC22017 was enhanced with $37.63 \%$ enzyme yield as compared to control. Enzyme activities in modified medium and control medium were $15.15 \pm 0.47 \mathrm{U} / \mathrm{ml}$ and $11.02 \pm$ $0.17 \mathrm{U} / \mathrm{ml}$, respectively. The results obtained in this study illustrated that the optimization of culture conditions played a pivotal role in influencing output through the fermentation bioprocess. Screening of microorganisms with higher $\alpha$-amylase activities could therefore facilitate the discovery of novel amylases suitable for new industrial applications. Purification and characterization of the enzyme are in progress.

\section{Materials and methods Sample collection}

Samples were collected from water and sediment of marine and salterns at different locations for isolation of bacteria. The samples were taken from Rashid, Sidi Bisher beach at Alexandria, Tiba rose village (El Sāhel Al-shamali), Hurghada, mangrove tree around the rhizosphere area (Marsa Alam), Safaga, El-Ain Elsokhna beach, and Wadi El-natron. Samples were collected in sterile bottles and brought to the lab, stored in the refrigerator at $4{ }^{\circ} \mathrm{C}$ until it was used.

Isolation and purification of $a$-amylase producing bacteria Sample was suspended into $90 \mathrm{ml}$ sterilized saline solution $(0.85 \%, \mathrm{NaCl})$ and diluted using the dilution method (Hayakawa and Nonomura 1987). Then, $100 \mu \mathrm{l}$ of diluted sample $\left(10^{-4}-10^{-6}\right)$ concentrations was placed on the starch agar plate and spreads with a sterile L-shaped glass rod (Kanimozhi et al. 2014). The plate was incubated at $50{ }^{\circ} \mathrm{C}$ for 24 and $48 \mathrm{~h}$, and single colonies of different sizes were selected. The colonies were subjected to purification to obtain single pure colonies.

\section{Screening of isolated samples for $a$-amylase production}

All isolates were curried using the starch plate (Moller et al. 2004). Bacteria were inoculated on starch plates to test for $\alpha$-amylase secretion, incubated at $50{ }^{\circ} \mathrm{C}$ for 3 days, and stains with an iodine solution (0.5\%). Amylase-positive stains were determined by the presence of a clear zone of starch hydrolysis around the colony on the starch plates, while presence of blue color around the growth indicated negative result (Hollo and Szeiti 1968). The bacterial isolates which produced a clear zone of hydrolysis in starch agar were selected as $\alpha$-amylase producers for subsequent investigation. Selected colonies were maintained on nutrient agar slants at $4{ }^{\circ} \mathrm{C}$ and sub-cultured monthly.

\section{Identification of potent amylase producer}

Biochemical, morphological, and physiological characteristics of the potential producer (isolate number 16) was determined by adopting standard methods (Bergey and Holt 1994). The identification was confirmed with phylogenetic analysis. Briefly, genomic DNA of bacteria was extracted and universal primer $5^{\prime}$-TCCGTAGGT GAACTTTGCGG- 3 ' and $5^{\prime}$-TCCTCCGCTTATTGATA TGC-3' primers was used for the amplification of DNA (Gardes and Bruns 1993). A single discrete PCR amplicon band was observed when resolved on agarose gel. The PCR amplicon was purified to remove contaminants. Sequencing products were resolved on an Applied Bio-systems model 3730XL automated DNA sequencing system (Applied BioSystems, USA). Data were submitted to GenBank database. The DNA sequence was compared to the GenBank database in the national Center for Biotechnology Information (https://www.ncbi.nlm. nih.gov/genbank/) using the BLAST program (Tamura et al. 2011). The sequencing was performed by Lab Technology Company.

\section{Growth conditions for a-amylase production}

To choose a proper culture medium for growth of the isolated strain and $\alpha$-amylase production, primarily five different fermentation media were examined: Medium 1 (g/l): $\mathrm{Na}_{2} \mathrm{HPO}_{4}$ 6.0, $\mathrm{KH}_{2} \mathrm{PO}_{4} 3.0, \mathrm{NaCl} 0.5, \mathrm{MgSO}_{4}$ 0.24, $\mathrm{CaCl}_{2}$ 0.01, Peptone 3.0, Starch 10.0 (Burhan et al. 2003). Medium 2 (g/l): Starch 10.0, Yeast extract 2.0, Peptone 5.0, $\mathrm{MgSO}_{4}$ 0.5, $\mathrm{NaCl} 0.5, \mathrm{CaCl}_{2} 0.15$ (Swain et al. 2006). Medium 3 (g/l): Starch 20.0, Peptone 0.5, $\mathrm{MgSO}_{4} .7 \mathrm{H}_{2} \mathrm{O}$ 0.5, $\mathrm{NaH}_{2} \mathrm{PO}_{4} 0.1,\left(\mathrm{NH}_{4}\right)_{2} \mathrm{SO}_{4} 0.1, \mathrm{KCl} 0.1$ (Mishra and Behera 2008). Medium 4 (g/l): Peptone 
10.0, Starch 5.0, Beef extract 10.0 (Amoozegar et al. 2003). Medium 5 (g/l): Starch 20, Peptone 10, Yeast extract $4, \mathrm{MgSO}_{4} 0.5, \mathrm{CaCl}_{2} 0.2$ (Kanimozhi et al. 2014). The $\mathrm{pH}$ of the media was adjusted to 7 with $0.1 \mathrm{~N} \mathrm{HCl}$ and $0.1 \mathrm{~N} \mathrm{NaOH}$. The media were sterilized and Erlenmeyer flasks of $100 \mathrm{ml}$ capacity containing $20 \mathrm{ml}$ of culture medium were inoculated with $1 \mathrm{ml}$ of previously prepared inoculum and incubated at $50{ }^{\circ} \mathrm{C}$ in a rotary shaker at $140 \mathrm{rpm}$ for $72 \mathrm{~h}$. The samples were harvested after $72 \mathrm{~h}$ and the cells were separated by centrifugation (5000 rpm for $15 \mathrm{~min}$ at $4{ }^{\circ} \mathrm{C}$ ) in centrifuge (SIGMA 3-18 KS). The cell dry weight (CDW) of culture broth was measured by harvesting the cells after centrifugation and drying them at $105{ }^{\circ} \mathrm{C}$ to a constant weight.

\section{Enzyme assay}

$\alpha$-Amylase activity was determined by measuring the reduction in blue color intensity resulting from enzyme hydrolysis of starch (Palanivelu 2001). The reaction mixture consisted of $200 \mu \mathrm{l}$ cell-free supernatant, $250 \mu \mathrm{l}$ of soluble starch $(1 \% w / v)$, and $500 \mu \mathrm{l}$ phosphate buffer $(0.2 \mathrm{M} \mathrm{pH} 7)$ incubated at $50{ }^{\circ} \mathrm{C}$ for $30 \mathrm{~min}$. The reaction was stopped by adding $250 \mu \mathrm{l}$ of $0.1 \mathrm{~N} \mathrm{HCl}$ and color was developed by adding $250 \mu \mathrm{l}$ of iodine solution. The optical density (OD) of the blue color solution was determined at $660 \mathrm{~nm}$ using (JASCO V-630) spectrophotometer. One unit $(\mathrm{U})$ of enzyme activity is defined as the amount of enzyme that hydrolyzes $0.5 \mathrm{mg}$ of starch per minute under assay optimum conditions. Specific activity was expressed as units of enzyme activity per $\mathrm{mg}$ of protein. All measurements were performed three times. The data were expressed as mean \pm standard error of the mean.

\section{Protein determination}

Protein content was estimated by Bradford's method (Bradford 1976) using bovine serum albumin as standard.

\section{Factors affecting a-amylase production from Bacillus sp. NRC22017}

Flask cultures were performed in $100 \mathrm{ml}$ Erlenmeyer flasks containing $20 \mathrm{ml}$ of the medium 5 . Factors affecting cell growth and $\alpha$-amylase production were investigated using one factor at a time method. The optimized parameters were incubation time (1, 2, 3, 4, and 5 days) at $50{ }^{\circ} \mathrm{C}$ under shaking conditions at $140 \mathrm{rpm}$, inoculum size $(100,200,300,400,500,600$, and $700 \mu \mathrm{l})$, medium volume $(10,15,20$, and $25 \mathrm{ml})$, temperature $(40,45,50$, and $\left.55{ }^{\circ} \mathrm{C}\right)$, and initial $\mathrm{pH}$ of the medium $(5.5,6.0,6.5$, 7.0, 7.5, and 8.0). Studies were also performed to evaluate the influence of different carbon sources (maltose, sucrose, xylose, fructose, and starch $2 \% w / v$ ) and different concentrations of starch $(0.5,1.0,1.5,2.0$, and $2.5 \% w / v)$. Also different nitrogen sources were used (peptone, yeast extract, peptone plus yeast extract, yeast plus meat extract, and peptone plus meat extract $1.4 \% \mathrm{w} / \mathrm{v}$ ) at different concentrations $(0.35,0.70,1.05$, and $1.40 \% w / v)$ of meat extract plus yeast extract were tested to get the best one for $\alpha$-amylase production. The enzyme activity and protein concentration were determined.

\section{Acknowledgements}

Not applicable.

\section{Funding}

This research was a part of MSc that was funded by national research center.

\section{Availability of data and materials}

All data generated or analyzed during this study are included in this published article [and its supplementary information files].

\section{Authors' contributions}

This research was extracted from MSc thesis. All authors read and approved the final manuscript.

\section{Ethics approval and consent to participate}

Not applicable (this study does not involve human participants, human data, or human tissue)

\section{Consent for publication}

Not applicable.

\section{Competing interests}

Purification and characterization of the enzyme are in progress.

\section{Publisher's Note}

Springer Nature remains neutral with regard to jurisdictional claims in published maps and institutional affiliations.

\section{Author details}

${ }^{1}$ Microbial Biotechnology Department, National Research Centre, El-Tahreer Street, Dokki, Cairo, Egypt. ${ }^{2}$ Microbiology Department, Faculty of Science, Ain Shams University, Cairo, Egypt.

Received: 31 July 2018 Accepted: 19 November 2018

Published online: 13 December 2018

\section{References}

Abdullah R, Shaheen N, Iqtedar M, Naz S, Iftikhar T (2014) Optimization of cultural conditions for the production of alpha amylase by Aspergillus Niger (BTM-26) in solid state fermentation. Pak J Bot 46(3):1071-1078

Ahmed K, Munawar S, Khan MA (2015) Cultural conditions for maximum alphaamylase production by Penicillium notatum IBGE 03 using shaken flask technique of submerged fermentation. Applied Biology 4(3):306-312

Aiyer PV (2005) Amylases and their applications. Afr J Biotechnol 4(13):1525-1529

Amoozegar MA, Malekzadeh F, Malik KA (2003) Production of amylase by newly isolated moderate halophile Halobacillus sp. strain MA-2. J of Microbiological Methods 52:353-359

Asad W, Asif M, Rasool SA (2011) Extracellular enzyme production by indigenous thermophilic bacteria: partial purification and characterization of $\alpha$-amylase by Bacillus sp. WA21. Pak J Bot 43(2):1045-1052

Asgher M, Asad MJ, Rahman SU, Legge RL (2007) A thermostable a-amylase from a moderately thermophilic Bacillus subtilis strain for starch processing. J of Food Engineering 79:950-955

Bansode SD (2010) Screening of nutritional components for a-amylase production in submerged fermentation by bacteria isolated from soil using plackettburman design. Int J Pharm PharmSci 2:93-98

Bergey DH, Holt GJ (1994) Bergey's manual of determinative bacteriology $9^{\text {th }}$ edition. The. Williams and Wilkins 428 East Preston street, Baltimore Maryland 21202, U.S.A

Bradford MM (1976) A rapid and sensitive analytical method for the quantitation of microgram quantities of protein utilizing the principle of protein-dye binding. Anal Biochem 72:284-254 
Burhan A, Nisa U, Gokhan C, Omer C, Ashabil A, Osman G (2003) Enzymatic properties of a novel thermophilic, alkaline and chelator resistant amylase from an alkalophilic Bacillus sp. isolate ANT-6. Process Biochem 38:1397-1403

Castro GR, Baigorí MD, Siñeriz F (1999) Studies on a-amylase production by Bacillus licheniformis MIR-61. Acta Biotechnol 19(3):263-272

Dash BK, Rahman MM, Sarker PK (2015) Molecular identification of a newly isolated Bacillus subtilis Bl19 and optimization of production conditions for enhanced production of extracellular amylase. BioMed Research international. Article ID 859805:9

Deb P, Talukdar SA, Mohsina K, Sarker PK, Sayem SA (2013) Production and partial characterization of extracellular amylase enzyme from Bacillus amyloliquefacien. Springer plus (2)1:154. https://doi.org/10.1186/2193-1801-2-154.

Demirkan ES, Mikami B, Adachi M, Higasa T, Utsumi S (2005) a-Amylase from B. amyloliquefaciens: purification, characterization, raw starch degradation and expression in E. coli. Process Biochem 40(8):2629-2636

Demirkan, Sevgi, Başkurt (2017) Optimization of physical factors affecting the production of the a-amylase from a newly isolated Bacillus sp. M10 strain Karaelmas Fen veMühendislikDergisi 7(1):23-30

El-Kady EM, Asker MS, Hassanein MS, Elmansy EA, El-Beih FM (2017) Optimization, production, and partial purification of thermostable a-amylase produced by marine bacterium Bacillus sp. NRC12017. International Journal of Pharmaceutical and Clinical Research 9(8):558-570

Ellaiah P, Adinarayana K, Bhavani Y, Padmaja P, Srinivasulu B (2002) Optimization of process parameters for glucoamylase production under solid state fermentation by a newly isolated Aspergillus species. Process Biochem 38: 615-620

Gangadharan D, Sivaramakrishnan S, Namboothiri KM, Pandey A (2006) Solid culturing of Bacillus amyloliquefaciens for a-amylase production. Food Technol Biotechnol 44(2):269-274

Gardes M, Bruns TD (1993) ITS primers with enhanced specificity for basidiomycetes-application to the identification of mycorrhizae and rusts. Mol Ecol 2:113-118

Goyal N, Gupta JK, Soni SK (2005) A novel raw starch digesting thermostable aamylase from Bacillus sp. I-3 and its use in the direct hydrolysis of raw potato starch. Enzym Microb Technol 37:723-734

Haq I, Ali S, Javed MM, Hameed U, Saleem A, Adnan F, Qadeer MA (2010) Production of a amylase from a randomly induced mutant strain of Bacillus amyloliquefaciens and its application as a desizer in textile industry. Pakistan J. of. Botany 42(1):473-484

Hasan MM, Marzan LW, Hosna A, Hakim, Azad AK (2017) Optimization of some fermentation conditions for the production of extracellular amylases by using Chryseobacterium and Bacillus isolates from organic kitchen wastes. Journal of Genetic Engineering and Biotechnology 15(1):59-68

Hayakawa M, Nonomura H (1987) Vitamin agar, a new medium for the selective isolation of soil actinomycetes. J of Fermentation Technology 65:501-509

Hollo J, Szeitli J (1968) The reaction of starch with iodine. In: Rodely JA (ed) Starch and its derivatives, 4th edn. Chapman and Hall, pp 203-246

Kanimozhi M, Midhusha Johny, Gayathri N, Subashkumar R (2014) Optimization and production of a-amylase from halophilic Bacillus species isolated from mangrove soil. J Appl Environ Microbiol 2(3):70-73

Kaur P, Vyas A (2012) Characterization and optimal production of alkaline aamylase from Bacillus sp. DLB 9. Afr J Microbiol Res 6(11):2674-2681

Maity S, Mallik S, Basuthakur R, Gupta S (2015) Optimization of solid state fermentation conditions and characterization of thermostable alpha amylase from Bacillus subtilis (ATCC 6633). J bioprocess. Biotechnol 5:1-7

Mishra S, Behera N (2008) Amylase activity of a starch degrading bacteria isolated from soil receiving kitchen waste. African J of Biotechnology 7:3326-3331

Moller K, Sharif MZ, Olsson L (2004) Production of fungal a-amylase by Sacccharomyces kluveri in glucose-limited cuttivations. J Biotechnology 111:311-318

NandLal, Jyoti J, Sachan P (2016) Optimization of nitrogen source(s) for the growth and amylase production from Bacillus licheniformis JAR-26 under submerged fermentation. Indian Journal of Biology. 3(2):127-132

NandLal, Jyoti J, Sachan P (2017) Optimization of carbon sources for the amylase production and growth of Bacillus licheniformis JAR-26 under submerged fermentation. Indian Journal of Biology 1(1):31-36

Narang S, Satyanarayana T (2001) Thermostable $a$-amylase production by an extreme thermophile Bacillus thermooleovorans. Lett Appl Microbiol 32:31-35

Nurullah A (2011) High level production of extracellular a-amylase from B. licheniformis ATCC 12759 in submerged fermentation. Rom Biotechnol Lett 16(6):6833-6840
Palanivelu P (2001) Analytical biochemistry and separation techniques. In: Kalamanin Printers. Madurai, India

Paul JS, Lall BM, Jadhav SK, Tiwari KL (2017) Parameter's optimization and kinetics study of a-amylase enzyme of Bacillus sp. MB6 isolated from vegetable waste. Process Biochem 52:123-129

Puspasari F, Radjasa OK, Noer AS et al (2013) Raw starch-degrading a-amylase from Bacillus aquimaris MKSC 6.2: isolation and expression of the gene, bioinformatics and biochemical characterization of the recombinant enzyme. J Appl Microbiol 114(1):108-120

Riaz N, Haq I, Qadeer M (2003) Characterization of a-amylase by Bacillus subtilis. International J. of Agriculture and. Biology 5(3):249-252

Saxena RK, Dutt K, Agarwal L, Nayyar P (2007) A highly thermostable and alkaline amylase from a Bacillus sp. PN5. Bioresour Technol 98(2):260-265

Sharma N, Vamil R, Ahmad S, Agarwal R (2012) Effect of different carbon and nitrogen sources on a-amylase production from Bacillus amyloliquefaciens. International J of Pharmaceutical Sciences and Research 3(4):1161-1163

Simair AA, Qureshi AS, Khushk I, Ali CH, Lashari S, Bhutto MA, Mangrio GS, Lu C (2017) Production and Partial characterization of a-amylase enzyme from Bacillus sp. BCC 01-50 and potential applications. BioMed Research International 2017, Article ID 9173040:9

Singh NR, Bahuguna A, Chauhan P, Sharma VK, Kaur S, Singh SK, Khan A (2016) Production, purification and characterization of thermostable a-amylase from soil isolate Bacillus sp. strain B-10. J. of bioscience and. Biotechnology 5(1):37-43

Singh P, Gupta P, Singh R, Sharma R (2012) Factors affecting alpha-amylase production on submerged fermentation by Bacillus sp. Int J Pha Life Sci 3(12):2243-2246

Sivakumar T, Ramasubramanian V, Shankar T, Vijayabaskar P, Anandapandian K (2011) Screening of keratinolytic bacteria Bacillus cereus from the feather dumping soil of Sivakasi. J Basic Appl Bio 5:305-314

Sivakumar T, Shankar T, Vijayabaskar P, Muthukumar J, Nagendrakannan E (2012) Amylase production using Bacillus cereus isolated from a Vermi compost site International J of Microbiology Research 3(2):117-123

Sivaramakrishnan S, Gangadharan D, Nampoothiri KM, Soccol CR, Pandey A (2006) a-Amylases from microbial sources-an overview on recent developments. Food Technol Biotechnol 44(2):173-184

Suribabu K, LalithaGovardhan T, Hemalatha KPJ (2014) Optimization of physical parameters of alpha amylase producing Brevibacillus borostelensis R1 in submerged fermentation. Int jr of Res Eng and Tech 1(03):517-525

Swain MR, Kar S, Padmaja G, Ray RC (2006) Partial characterization and optimization of production of extracellular a-amylase from Bacillus subtilis isolated from culturable cow dung microflora. Polish J. of. Microbiology 55(4): 289-296

Tamura K, Peterson D, Peterson N, Stecher G, Nei M, Kumar S (2011) MEGA5: molecular evolutionary genetics analysis using maximum likelihood, evolutionary distance and maximum parsimony methods. Mol Biol Evol 28: $2731-2739$

Teodoro CED, Martin MLL (2000) Culture conditions for the production of thermostable amylase by Bacillus sp. Braz J Microbiol 31(1517-8382):298-302.

Thippeswamy S, Girigowda K, Mulimani VH (2006) Isolation and identification of a-amylase producing Bacillus sp. from dhal industry waste. Indian J Biochem Biophys 43(5):295-298

Tiwari S, Shukla N, Mishra P, Gaur R (2014) Enhanced production and characterization of a solvent stable amylase from solvent tolerant bacillus tequilensis rg-01: thermostable and surfactant resistant. Sci World J 2014, Article ID 972763:11

Tonkova A (2006) Microbial starch converting enzymes of the a-amylase family. In: Microbial biotechnology in horticulture, R.C. ray and O.P. wards (Ed.), pp. (421-472), science publishers, Enfield, IS BN, vol 9781578084173. New Hampshire, USA

Vijayaraghavan P, Kalaiyarasi M, Vincent SGP (2015) Cow dung is an ideal fermentation medium for amylase production in solid-state fermentation by Bacillus cereus. Journal of Genetic Engineering and Biotechnology 13(2):111-117

Yegneswaran PK, Gray MR (1991) Effect of dissolved oxygen control on growth and antibiotic production in Streptomyces clavuligerus fermentations. Biotechnol Prog 7(3):246-250

Zambare V (2011) Optimization of amylase production from Bacillus sp. using statistics based experimental design. Emirates J of Food and Agriculture 23(1):37-47 